2. To: (Receiving Organization)

Environmental Integration

5. Proj./Prog./Dept./Div.:

W-420/TWRS

8. Originator Remarks:

Distribute per attached distribution cover sheet.
3. From: (Originating Organization) TWRS Upgrade Projects

6. Design Authority/ Design Agent/Cog. Engr.:

KE Carpenter (PM W-420)
4. Related EDT No.:

$\mathrm{N} / \mathrm{A}$

7. Purchase Order No.:

N/A

9. Equip./Component No.:

$\mathrm{N} / \mathrm{A}$

10. System/Bldg./Facility:

241-Genera1

11. Receiver Renarks: 11A, Design Baseline Document? [] Yes [X] No
12. Major Assm. Dwg. No.:

$N / A$

13. Permit/Permit Application No.: N/A

14. Required Response Date: 09/30/98

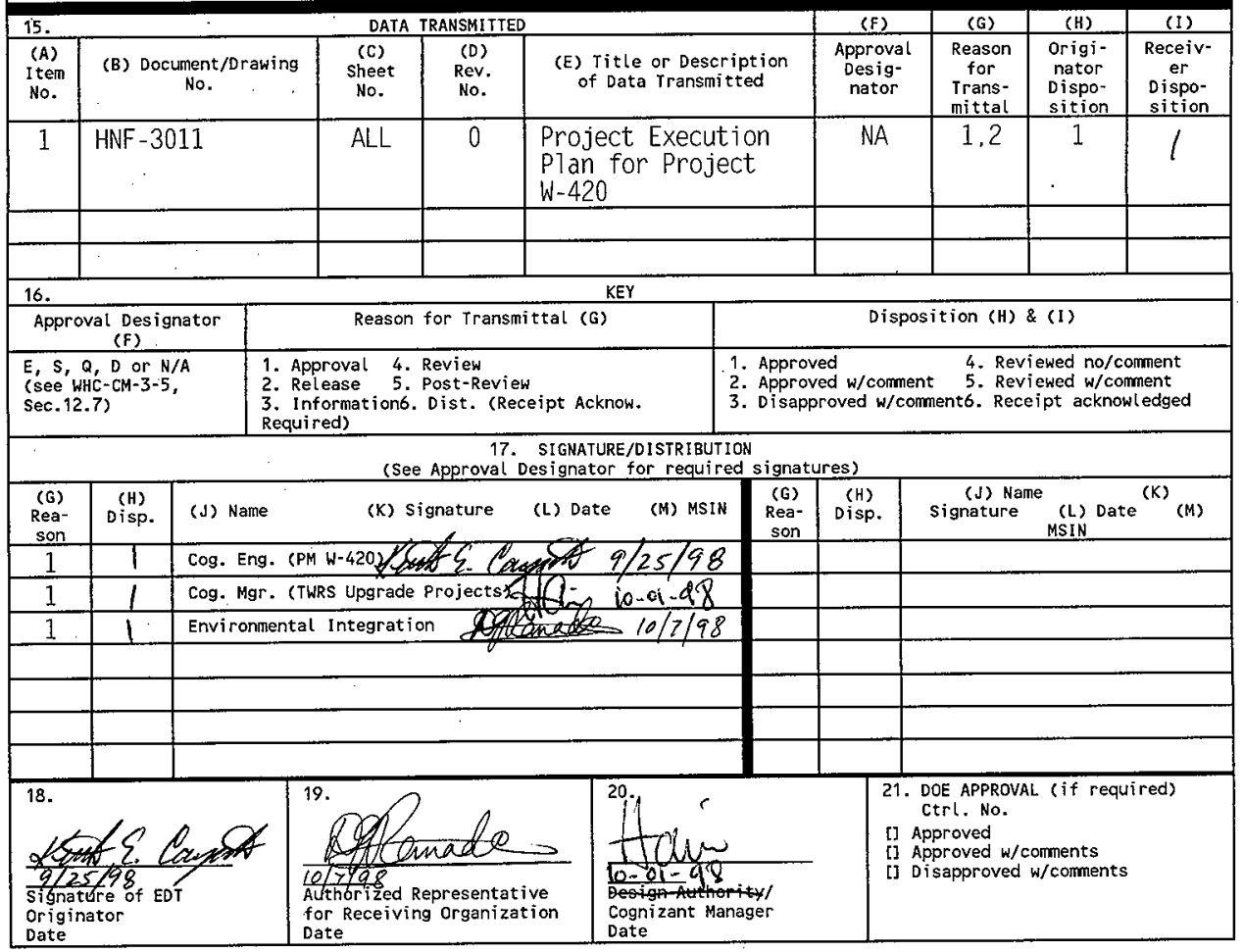


HNF-3011, Rev. 0

\section{Project W-420 Stack Monitoring System Upgrades}

Keith Carpenter

Numatec Hanford Corp., Richland, WA 99352

U.S. Department of Energy Contract DE-AC06-96RL13200

EDT/ECN: 625699

Org Code: 81200

UC: 2000

B\&R Code: EW3120100

Charge Code: 103211 CA40

Total Pages: 33

Key Words: execution, execution plan, record sampler, stack monitoring system, upgrades, Project $W-420$

Abstract: This project wi11 execute the design, procurement. construction. startup, and turnover activities for upgrades to the stack monitoring system on selected Tank Waste Remediation System (TWRS) ventilation systems. In this plan, the technical, schedule, and cost baselines are identified, and the roles and responsibilities of project participants are defined for managing the Stack Monitoring System Upgrades, Project $W-420$.

TRADEMARK DISCLAIMER. Reference herein to any specific comercial product, process, or service by trade name, trademark, manufacturer, or otherwise, does not necessarily constitute or imply its endorsenent, recommendation, or favoring by the United States Government or any agency thereof or its contractors or subcontractors.

Printed in the United States of America. To obtain copies of this document, contact: Document Control Services, P.O. Box 950, Mailstop H6-08, Richland WA 99352, Phone (509) 372-2420;

Fax (509) 376-4989.
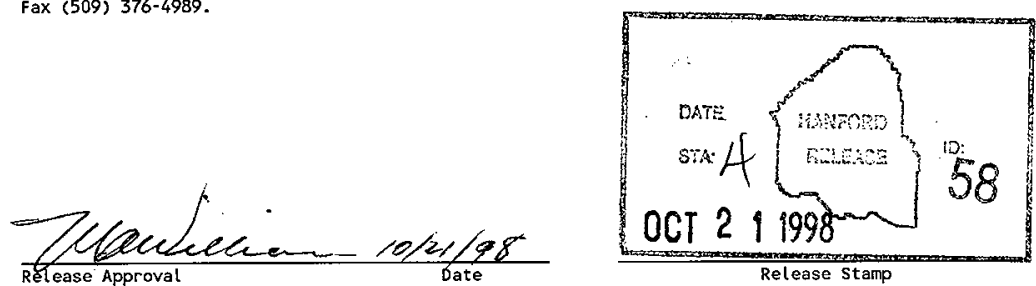

Approved for Public Release 
Stack Monitoring System Upgrades

$$
\text { Project W-420 }
$$

\title{
Project Execution Plan
}

(HNF-3011)

\section{Numatec Hanford Corporation \\ Richland, Washington}

\author{
September 1998
}




\title{
NUMATEC HANFORD CORPORATION
}

\author{
PROJECT EXECUTION PLAN \\ FOR PROJECT W-420 \\ STACK MONITORING SYSTEM UPGRADES
}

HNF-3011

Revision 0
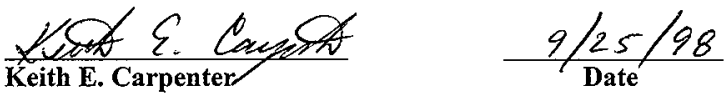

Project Manager, W-420

Numatec Hanford Corporation

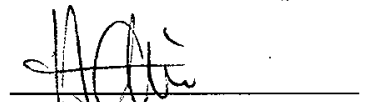

Pierte A. Haine

$$
\frac{10.01 \cdot 98}{\text { Date }}
$$

Manager, TWRS Upgrade Projects

Numatec Hanford Corporation

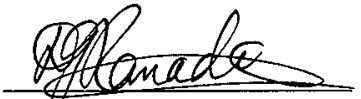

Digłmbar G. Ranade

Program Manager, W-420

Fluor Daniel Hanford, Inc.

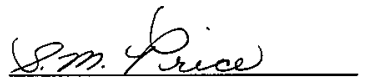

Susan M. Price

$\frac{10-6-98}{\text { Date }}$

Manager, EnvironmentaI Integration

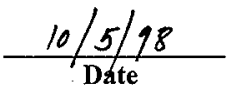

Fluor Daniel Hanford, Inc. 
CONTENTS

1.0 PROJECT OBJECTIVES

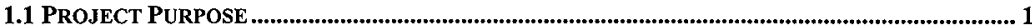

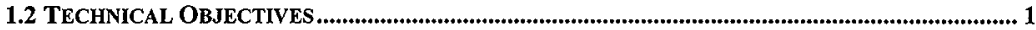

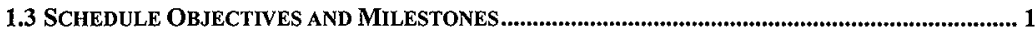

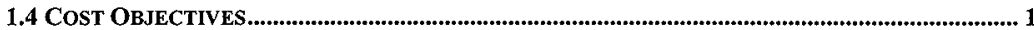

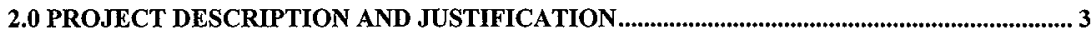

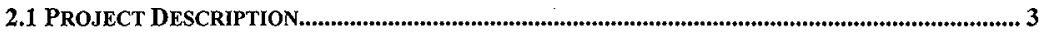

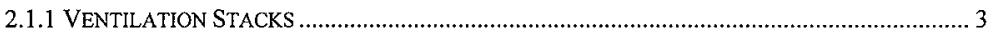

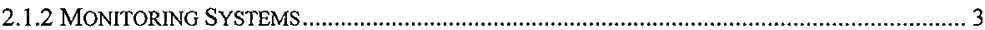

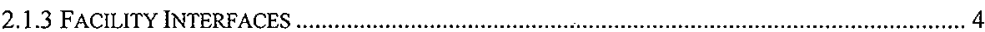

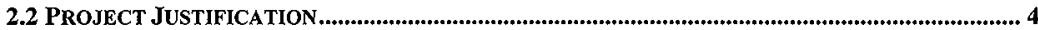

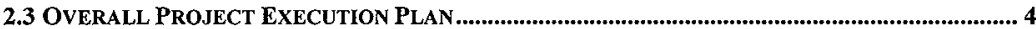

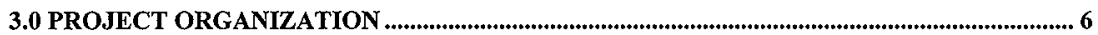

3.1 U.S. DEPARTMENT OF ENERGY, RICHLAND OPERATIONS OFFICE......................................... 6

3.2 MANAGING CONTRACTOR (MC), FluOR DANIEL HANFORD, INC. (FDH) ............................. 8

3.3 Waste Management Contractor, Waste Management Federal Services of

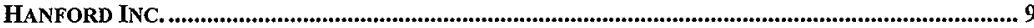

3.4 TWRS OPERATION CONTRACTOR, LOCKHEED-MARTIN HANFORD CORPORATION ............. 9

3.5 PROJECT OFFICE, NUMATEC HANFORD CORPORATION ...................................................... 10

3.6 SAFETY ANALYSIS CONTRACTOR, DE\&S HANFORD, INC................................................... 12

3.7 HANFORD INFRASTRUCTURE CONTRACTOR, DYNCORP TRI-CITIES SERVICES, INC............. 12

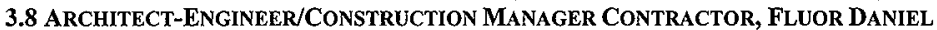

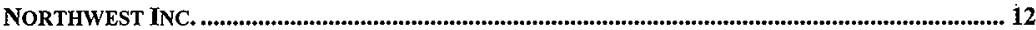

3.9 HANFORD INFORMATION SYSTEM CONTRACTOR (ISC), LOCKHEED-MARTIN SERVICES, INC.

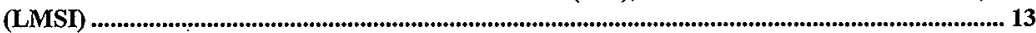

4.0 PROJECT MANAGEMENT SYSTEMS AND CONTROLS............................................... 14

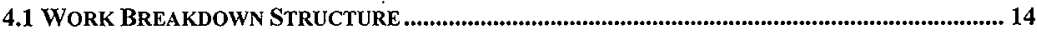

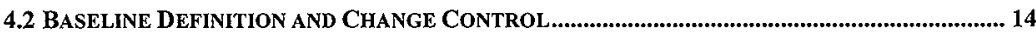

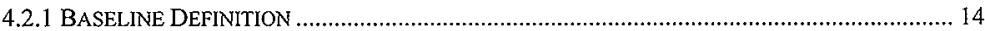

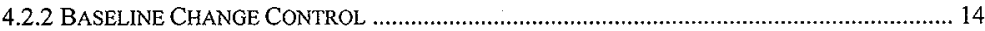

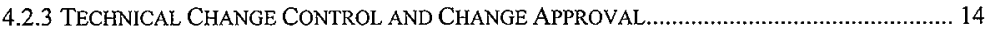

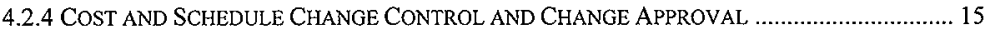

4.2.5 CONTRACTOR CHANGE CONTROL INFORMATION .................................................. 15

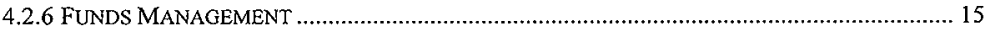

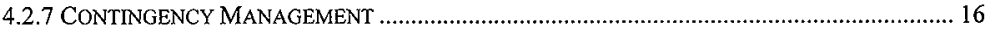

4.3 Risk MANagement, PERformance Monitoring, Reporting, AND Forecasting....... 16

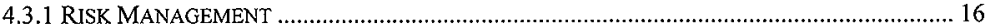


4.3.2 PERFORMANCE MONITORING, REPORTING, AND FORECASTING ................................ 16

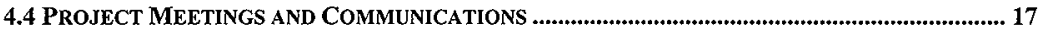

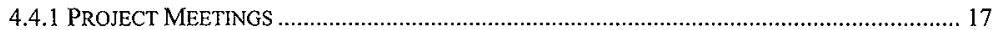

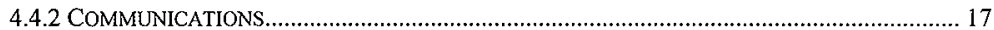

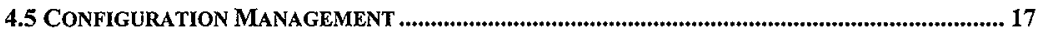

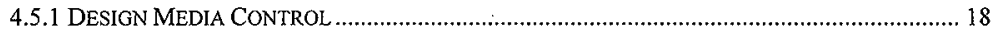

4.6 AUDITS, SURVEILLANCES, AND ASSESSMEVTS ...................................................................... 18

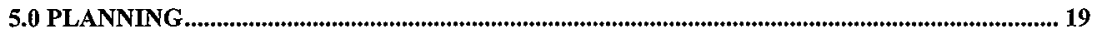

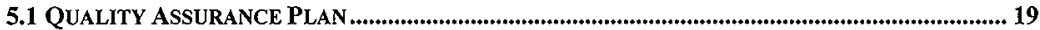

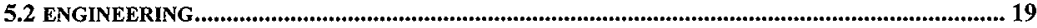

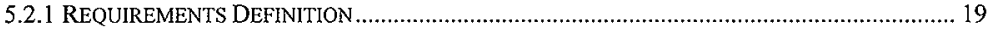

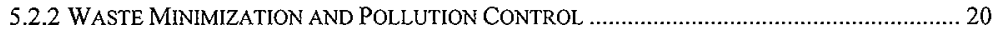

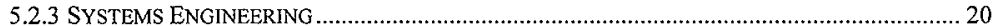

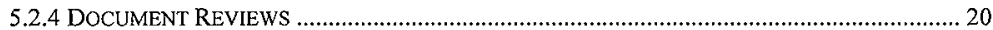

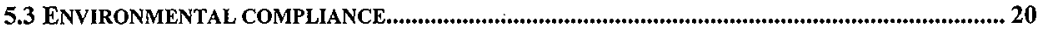

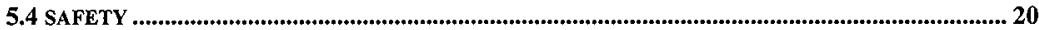

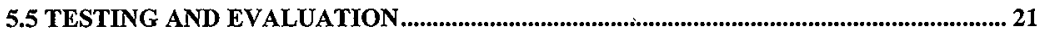

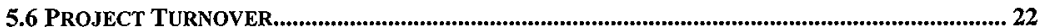

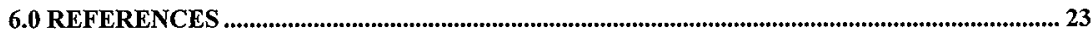




\subsection{PROJECT OBJECTIVES}

This document provides the organizational responsibilities and baseline controls to be used for the execution of Project W-420, Stack Monitoring System Upgrades. A project description, justification, objectives, and planning bases are also included.

\subsection{PROJECT PURPOSE}

This project will execute the design, procurement, construction, startup, and turnover activities for upgrades to the stack monitoring system on selected Tank Waste Remediation System (TWRS) ventilation systems. Modifications to existing facilities and installation of compliant monitoring systems are conceptualized in HNF-SD-W420-CDR-001, Conceptual Design Report for Project W-420, Stack Monitoring Upgrade (Tuck 1998).

\subsection{TECHNICAL OBJECTIVES}

The technical objectives for representative sampling of ventilation exhaust streams are based on historical data from the Hanford Site and other U.S. Department of Energy (DOE) sites. The project's technical baseline, which includes bases and criteria for the stack upgrades and monitoring systems, is found in HNF-SD-W420-FDC-001, Functional Design Criteria for Project W-420, Stack Monitoring Upgrade (Tuck 1998).

\subsection{SCHEDULE OBJECTIVES AND MILESTONES}

The schedule objectives are shown in Figure 1. The schedule depicts the major activities of the work breakdown structure (WBS). The major milestone for beginning construction is consistent with negotiated dates for the Federal Facilities Compliance Agreement (EPA 1994). Additional major milestones include the completion of construction, declaration of readiness, and project completion.

\subsection{COST OBJECTIVES}

The conceptual design included developing the project's total project cost (TPC) estimate. The total estimated cost (TEC) was established using a bottom-up method based on the design media and outline specifications produced during conceptual design and other development activities. The Project Office (PO) provided the other project costs (OPC) required to support project execution. A detail of the TEC and TPC are provided in HNF-SD-W420-CDR-001, Conceptual Design Report for Project W-420, Stack Monitoring Upgrade (Tuck 1998), including the objectives for engineering, procurement, construction, project management, $\mathrm{OPC}$, and contingencies for each system and the entire project. These cost objectives were subjected to an independent cost evaluation and were validated as a capital line item project budget in May 1997. Cost objectives were modified during fiscal year 1998 in order to line up with the PHMC approved revisions to the project technical and schedule baselines. 


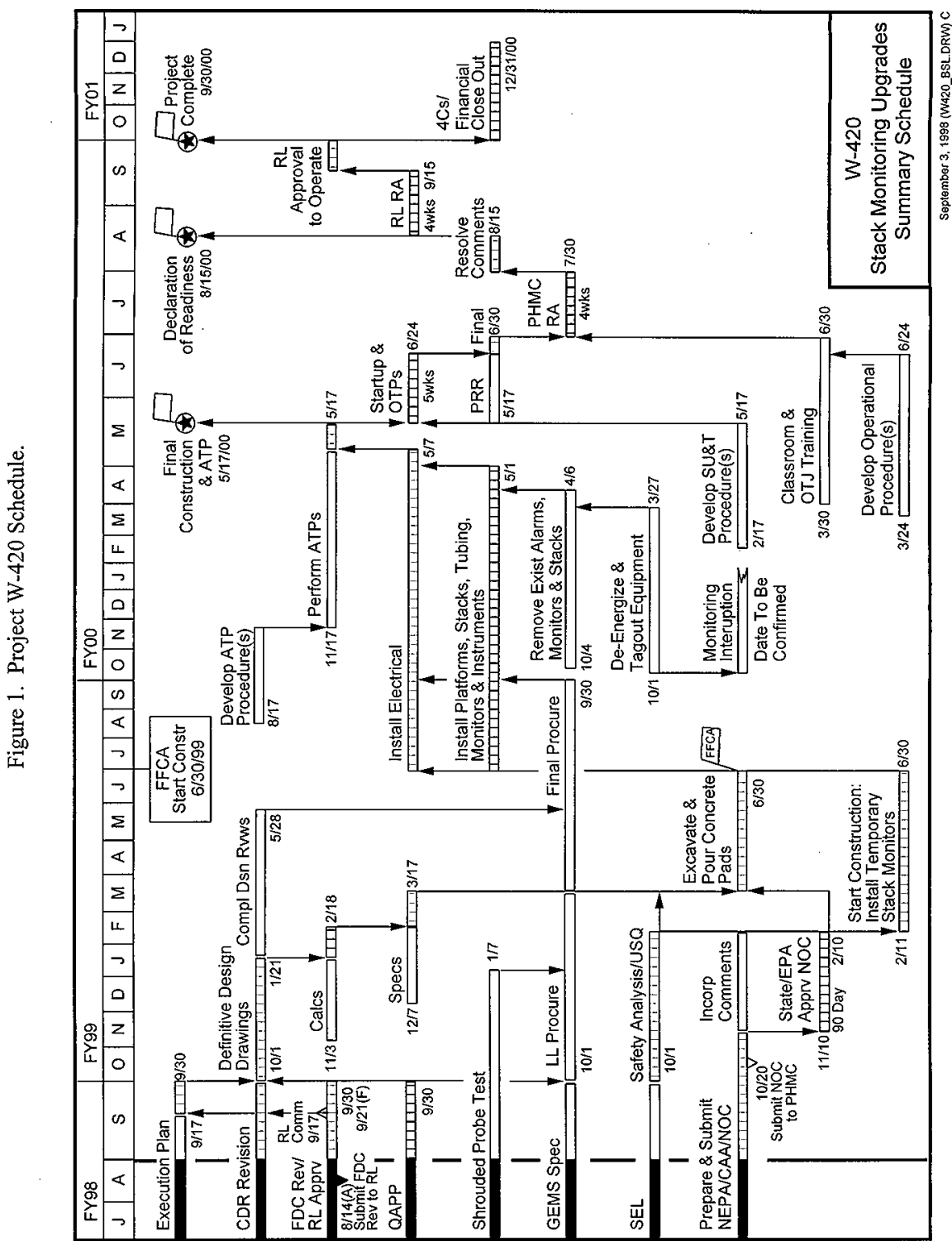




\subsection{PROJECT DESCRIPTION AND JUSTIFICATION}

\subsection{PROJECT DESCRIPTION}

The project will modify existing facilities and provide compliant monitoring systems for six TWRS major ventilation system stacks. Major stacks must meet the monitoring requirements of Title 40, Code of Federal Regulations. (CFR), Part 61 Subpart H. These regulations require sampling to be compliant with American National Standards Institute (ANSI) standard N13.1 or to be performed by the U.S. Environmental Protection Agency (EPA)-approved single-point sampling method. The following stacks require upgrades for compliant sampling:

- 296-A-25 (244-A DCRT)

- 296-B-28 (244-BX DCRT)

- 296-C-5 (244-CR Vault)

- 296-P-16 (241-C Tank Farm)

- 296-S-22 (244-S DCRT)

- 296-T-18 (244-TX DCRT).

\subsubsection{Ventilation Stacks}

The decision to use an existing stack configuration or replace or modify a stack is based on whether the existing stack can provide satisfactory locations for sample and flow sensing probes. New stack extensions, modifications to existing stacks, or replacement stacks are specified as required to meet functional criteria. The current baseline for Project W-420 is to replace all the affected stacks except stack 296-C-5.

\subsubsection{Monitoring Systems}

A gaseous effluent monitoring system (GEMS) will be installed at each exhaust stack to monitor and trend the concentration of radioactive materials released to the environment. The GEMS will extract representative samples; measure and total stack velocity and flow rate; measure, control, and total sample flow rates; and monitor the sample flow to determine air emissions. Each system shall contain the following equipment as required to meet stack-specific requirements:

- Instrument cabinets

- Stack flow instrumentation

- Sample collection system

- Particulate record sampler

- Particulate beta-gamma continuous monitor

- Particulate alpha continuous monitor

- Sample flow instrumentation

- Data logging system

- Vacuum system. 
HNF-3011, Rev, 0

\subsubsection{Facility Interfaces}

The construction project will provide facility interfaces for power, instrument signals, and mechanical components. Electrical power will be provided from the panel boards that currently supply the existing stack monitors. The new air sampling and monitoring system will provide instrument signals for alarms, indicators, and ventilation system interlocks. Mechanical components will provide the interface between the new stacks and the existing exhaust stream.

\subsection{PROJECT JUSTIFICATION}

A Federal Facilities Compliance Agreement (FFCA) between the U.S. Department of Energy, Richland Operations Office (RL) and the EPA, Region 10, was established on February 7, 1994. The FFCA includes a series of activity milestones required for the Hanford Site to affirm compliance with the "National Emission Standard for Hazardous Air Pollutants" (NESHAP). Milestone activities include upgrading the sampling and monitoring systems for the major stacks identified in WHC-SD-WM-EMP-031, Tank Farms' Stack NESHAP Designation (Crummel 1998), as being noncompliant with NESHAP. Major stacks are those source points with potential radionuclide emissions that could cause any member of the public to receive an effective dose equivalent of greater than 0.1 millirem per year.

Completion of Project W-420 will fulfill the remaining FFCA milestones and provide NESHAP compliance for the Hanford Site. Achieving NESHAP compliance will allow RL to apply for an exemption under 40 CFR 61.96(b). The EPA granting the exemption will eliminate the need for prior EPA approval of facility construction and modifications where the effective dose equivalent to any member of the public is less than 0.1 millirem per year.

\subsection{OVERALL PROJECT EXECUTION PLAN}

During the third quarter of government fiscal year (GFY) 1997, Project W-420 was validated as a line-item project. In the second quarter of GFY 1998, the ceiling for general plant projects (GPP) was raised to cover projects with a TPC of less than $\$ 5$ million. For this reason, the project will be executed as a GPP following the guidance of DOE O 430.1, Life Cycle Asset Management, and that order's good practice guides.

Project activities performed by the Project Hanford Management Contract (PHMC) managing contractor (MC) and its major subcontractors will be performed and documented according to procedures issued by the MC, Fluor Daniel Hanford, Inc. In addition to the procedures listed in this document, the project will follow requirements defined in PHMC procedures HNF-PRO-1997, Construction Program Overview; HNF.PRO-551, Construction Program; and HNF-PRO-552, Project Control. These specific procedures reference additional applicable procedures.

Work performed by the companies contracted to the MC's subcontractors may be performed in accordance with the PHMC procedures. These companies also may use their internal procedures to perform work as long as their procedures do not incur additional costs to the $\mathrm{MC}$ and DOE. Exceptions to this approach will be included in task orders, statements of 
work, or contract special conditions. Deliverables that must be released into the PHMC document system will be provided to the Hanford Site in a suitable format as defined in special contract conditions.

Equipment will be acquired and facilities modified using numerous contracting mechanisms. The current baseline is to request proposals for the procurement of major system components. The architect engineer-construction management (AE-CM) contractor will provide installation design and interface components for the operation of the modified systems. 


\subsection{PROJECT ORGANIZATION}

This section describes the responsibilities, approval authorities, and actions required of each participating organization for the duration of the project beginning in October 1998. The project organization will include up to seven companies contracted to RL either directly or through subcontracts. Tasks performed by these companies can be accomplished either by modifying existing contracts or providing new contracts. RL, EPA, and Washington State are also involved in executing this project.

The assigned responsibilities for each participating project organization reflect the contractual requirements and agreements established. These responsibilities are outlined in Sections 3.1 through 3.11 and also are listed in the project roles and responsibility matrix as shown in Table 2.

\subsection{U.S. DEPARTMENT OF ENERGY, RICHLAND OPERATIONS OFFICE}

A designated $\mathrm{RL}$ project organization is responsible for overall management and execution of projects. Project management within the $\mathrm{RL}$ coordinates with other $\mathrm{RL}$ divisions and staff as necessary. The RL project office will authorize and fund MC project activities. The $\mathrm{RL}$ project office is the single point of contact with the performing project organization during design and construction. This office reviews and approves key documents or coordinates their approval.

The RL project office has the following responsibilities:

- Reviews project TEC and TPC cost estimates, including supporting materials, provided by the MC before initiation of design, procurements, or construction through the budget validation process.

- Approves, issues authorization, and provides funds for the $\mathrm{MC}$ to perform work.

- Conducts the monthly management review meetings.

- Provides advice and assistance in accordance with assigned functional responsibilities during project development, authorization, and execution.

- Provides surveillance and audits of project execution to ensure compliance with DOE directives and orders.

- Ensures construction projects are executed in a manner consistent with applicable DOE approved policies, directives, requirements, and standards.

- Transmits to DOE, Headquarters, copies of the project documentation and applicable supporting information, as required.

- Approves all changes to the functional design criteria (FDC). 
HNF-3011, Rev. 0

Table 2. Project Roles and Responsibilities Matrix

\begin{tabular}{|c|c|c|c|c|c|c|c|c|}
\hline & $\begin{array}{l}\text { DOE- } \\
\text { RL }\end{array}$ & $\begin{array}{l}\text { FDH } \\
(\mathrm{MC})\end{array}$ & $\begin{array}{l}\mathrm{NHC} \\
\text { (PO) }\end{array}$ & $\begin{array}{l}\text { LMHC } \\
\text { (OC) }\end{array}$ & $\begin{array}{l}\text { WMFS } \\
\text { (WMC) }\end{array}$ & $\begin{array}{l}\text { DESH } \\
\text { (SAC) }\end{array}$ & $\begin{array}{l}\text { FDNW } \\
(\mathrm{AE} / \mathrm{CM})\end{array}$ & $\begin{array}{l}\text { LMSI } \\
\text { (ISC) }\end{array}$ \\
\hline Functional Design Criteria & A & A & $\mathrm{P}$ & $\bar{A}$ & $\mathrm{R}, \mathrm{I}$ & - & $I$ & - \\
\hline Conceptual Design Report & - & $\mathrm{A}$ & A & A & R, I & - & $\bar{P}$ & - \\
\hline Project Data Sheet & - & $A$ & $\mathrm{P}$ & - & - & - & - & $=$ \\
\hline Project Execution Plan & - & $\mathrm{A}$ & $\mathrm{P}$ & - & $\mathrm{R}, \mathrm{I}$ & - & $\mathrm{R}, \mathrm{I}$ & - \\
\hline $\begin{array}{l}\text { Design Authority (Design Baseline } \\
\text { Documents) }\end{array}$ & - & - & - & $\mathrm{P}$ & - & - & - & - \\
\hline Definitive Design & - & $\mathrm{R}$ & $\mathrm{A}$ & A & $\mathrm{R}$ & $\mathrm{R}$ & $\mathrm{P}$ & 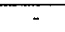 \\
\hline $\begin{array}{l}\text { Environmental Documents (NEPA, } \\
\text { NOC...) }\end{array}$ & - & $\mathrm{R}$ & A & $\mathrm{R}, \mathrm{I}$ & $\mathrm{P}$ & - & $\bar{R}$ & - \\
\hline Safety Analysis (USQs) & - & - & A & $\mathrm{R}, \mathrm{I}$ & - & $\mathrm{P}$ & - & - \\
\hline Quality Assurance Plan & - & $\mathrm{A}$ & A & A & - & - & $\mathbf{P}$ & - \\
\hline Change Control $\$>$ TEC/TPC & A & A & $\mathrm{P}$ & - & - & - & $\mathrm{R}, \mathrm{I}$ & - \\
\hline $\begin{array}{l}\text { Change Control } \$>25 \% \\
\text { Contingency }\end{array}$ & - & $\bar{A}$ & $\mathrm{P}$ & - & - & - & $\mathrm{R}, \mathrm{I}$ & - \\
\hline Change Control $\$>$ FDNW Contract & - & $\overline{-}$ & A & - & - & - & $P$ & - \\
\hline Change Control Milestones (FFCA) & A & $\bar{A}$ & $\mathrm{P}$ & - & I & - & I & - \\
\hline $\begin{array}{l}\text { Change Control Schedule }>180 \\
\text { Days }\end{array}$ & A & $\mathrm{A}$ & $\mathrm{P}$ & - & I & - & I & - \\
\hline Change Control Schedule $>90$ Days & $\overline{-}$ & A & $\mathrm{P}$ & I & - & - & I & - \\
\hline $\begin{array}{l}\text { Project Document \& Records } \\
\text { Management }\end{array}$ & - & - & I & I & I & - & I & $\bar{P}$ \\
\hline $\begin{array}{l}\text { Design Document Records } \\
\text { Management }\end{array}$ & - & - & I & - & - & - & $\mathbf{P}$ & I \\
\hline Procurement Specifications & - & $\mathrm{R}$ & A & - & $\mathrm{R}, \mathrm{I}$ & - & $P$ & - \\
\hline Construction Management & - & - & A & $\mathrm{R}, \mathrm{I}$ & - & - & $\mathrm{P}$ & - \\
\hline Tie-in \& Excavation Permits & - & - & $\tilde{R}, I$ & A & - & - & $\mathrm{P}$ & - \\
\hline Acceptance Inspection & A & $P$ & $\mathrm{R}, \mathrm{I}$ & $\mathrm{R}, \mathrm{I}$ & - & - & I & - \\
\hline
\end{tabular}


HNF-3011, Rev. 0

\begin{tabular}{|l|c|c|c|c|c|c|c|c|}
\hline & $\begin{array}{c}\text { DOE- } \\
\text { RL }\end{array}$ & $\begin{array}{c}\text { FDH } \\
(\mathrm{MC})\end{array}$ & $\begin{array}{c}\text { NHC } \\
\text { (PO) }\end{array}$ & $\begin{array}{c}\text { LMHC } \\
\text { (OC) }\end{array}$ & $\begin{array}{c}\text { WMFS } \\
\text { (WMC) }\end{array}$ & $\begin{array}{c}\text { DESH } \\
\text { (SAC) }\end{array}$ & $\begin{array}{c}\text { FDNW } \\
\text { (AE/CM) }\end{array}$ & $\begin{array}{c}\text { LMSI } \\
\text { (ISC) }\end{array}$ \\
\hline $\begin{array}{l}\text { Acceptance \& Operability } \\
\text { Procedures \& Tests }\end{array}$ & - & - & $\mathrm{A}$ & $\mathrm{P}$ & - & - & $\mathrm{P}$ & - \\
\hline As-Built Drawings & - & - & $\mathrm{R}, \mathrm{I}$ & $\mathrm{A}$ & - & - & $\mathrm{P}$ & - \\
\hline $\begin{array}{l}\text { Construction Complete \& Cost } \\
\text { Close }\end{array}$ & $\mathrm{R}$ & $\mathrm{R}$ & $\mathrm{P}$ & $\mathrm{R}$ & - & - & $\mathrm{I}$ & - \\
\hline Official Acceptance of Construction & $\mathrm{A}$ & $\mathrm{A}$ & $\mathrm{P}$ & $\mathrm{A}$ & - & - & $\mathrm{I}$ & - \\
\hline O \& M Procedures and Training & - & - & $\mathrm{A}$ & $\mathrm{P}$ & - & - & $\mathrm{I}$ & - \\
\hline
\end{tabular}

$A=$ Review \& Approve $P=$ Prepare/Perform \& Approve

$\mathrm{R}=$ Review \& Comment

I = Provide Input

- Approves all changes to the schedules, costs, and required funds that exceed established threshold values.

- Provides the formal interface between the project and the EPA.

- Establishes the reporting protocol for job site safety incidents.

\subsection{MANAGING CONTRACTOR (MC), FLUOR DANIEL HANFORD, INC. (FDH)}

The MC provides the interface between $\mathrm{RL}$ and the performing organizations. The performing organizations include the waste management contractor (WMC), Waste Management Federal Services of Hanford, Inc., the TWRS operations contractor (OC), Lockheed-Martin Hanford Corporation and the project office (PO), Numatec Hanford Corporation. The MC performs a number of activities related to project execution including the following:

- Obtains program direction from RL.

- Requests funding and changes to project authorizations by submitting a request for modifications to the RL.

- Reviews, approves, and submits project documentation prepared by the performing organization for RL approval.

- Provides monthly project reports to RL and participates in monthly and quarterly project management review meetings.

- Exercises control over the established technical, cost, and schedule baseline through the $\mathrm{MC}$ change control board. 
- Assigns technical and daily project management responsibilities to the WMC, OC, PO, and other performing organizations. This includes developing project-specific technical requirements, planning, scheduling, estimating, design coordination and control, procurement, construction, and testing.

- Prepares acceptance inspection plans and performs acceptance inspection of the project for RL.

- Supports project construction activities with health physics technicians through the major Site contractors.

\subsection{WASTE MANAGEMENT CONTRACTOR, WASTE MANAGEMENT FEDERAL SERVICES OF HANFORD INC.}

The WMC performs a number of activities related to project execution including:

- Providing inputs to, and reviewing, the project's design requirements.

- Providing technical assistance for the sampling system testing and design.

- Supporting the project air and water regulatory permitting (Notice of Construction).

- Providing the contractor project interface with applicable regulators.

\subsection{TWRS OPERATION CONTRACTOR, LOCKHEED-MARTIN HANFORD CORPORATION}

The OC performs the following activities related to project execution:

- Reviewing and approving project documentation prepared by the PO for approval by the MC.

- Providing design authority approval on all installation design media and system design bases documentation prepared by the PO.

- Conducting operational readiness reviews with $\mathrm{RL}$, the $\mathrm{MC}$, and the PO.

- Accepting systems, structures, and components installed by Project W-420 for use.

- Participating in acceptance tests and conducting operability tests.

- Providing project support for quality assurance, health physics technicians, industrial safety, fire protection, field work control, and environmental permitting.

- Providing construction site support. 


\subsection{PROJECT OFFICE, NUMATEC HANFORD CORPORATION}

The $\mathrm{PO}$ is responsible for the technical direction and management of the project and for ensuring that the project is completed in accordance with the approved project baseline. The PO coordinates project activities with the user organizations and ensures that the project complies with technical, quality, safety, safeguards, security, and environmental requirements. The PO organization, shown in Figure 3, performs the following activities:

- Managing the technical and daily project activities and aligning and controlling design, procurement, and construction activities.

- Developing and submitting all required project documentation to the MC.

- Requesting funding and changes to project authorization by submitting a request for modification to the MC.

- Approving the definitive design for compliance with the functional requirements and project baseline. Evaluating the design to ensure that it meets safety and operability requirements and is cost effective.

- Supporting administration of baseline change control with the MC.

- Providing a focal point for coordinating project activities with other contractor organizations.

- Approving design and construction schedules from the AE-CM for consistency with project requirements.

- Ensuring that the design is optimized in the areas of cost, safety, reliability, maintainability, accuracy, and compliance with applicable codes, standards, requirements, regulations, and DOE directives.

- Supporting development of official project files.

- Obtaining program direction from the $\mathrm{MC}$.

- Preparing monthly and quarterly reports for the MC and RL.

- Leading the processing of all Site construction-related permits; including excavation, tiein, power deactivation, and system isolation.

- Accomplishing work through other Site performing organizations using contract modifications.

- Managing the stack qualification and shrouded probe testing. 
Figure 3. Project Office Execution Hierarchy

\section{Project Management W-420 \\ Execution Hierarchy \\ FY '99 \& '00}

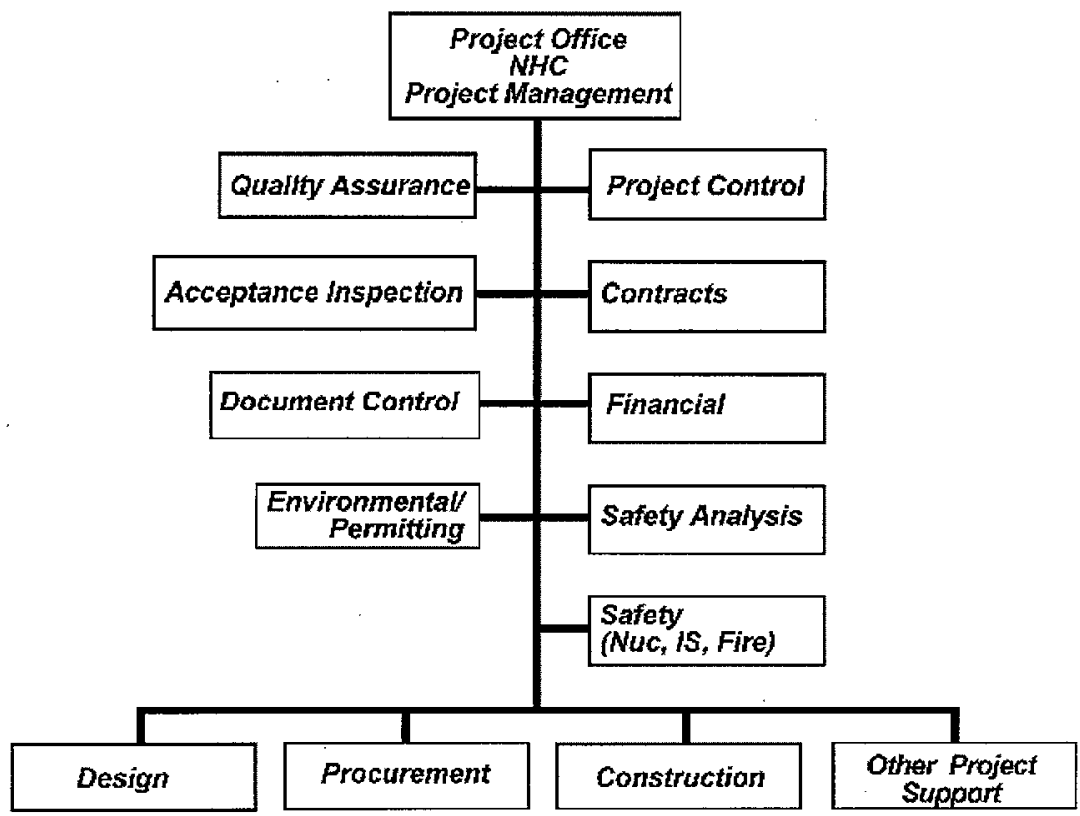




\subsection{SAFETY ANALYSIS CONTRACTOR, DE\&S HANFORD, INC.}

The safety analysis contractor (SAC) will provide safety screening of the project systems, structures, and components. Screenings for unreviewed safety questions (USQ) will focus on potential impacts to the TWRS Authorization Basis.

\subsection{HANFORD INFRASTRUCTURE CONTRACTOR, DYNCORP TRI-CITIES SERVICES, INC.}

The infrastructure contractor (IC) will support applicable construction activities during project execution.

\subsection{ARCHITECT-ENGINEER/CONSTRUCTION MANAGER CONTRACTOR, FLUOR DANIEL NORTHWEST INC.}

The AE-CM is responsible for the facility design and installation of the upgraded stack monitoring systems. Specifically, the AE-CM performs the following activities:

- Provides design services to ensure that established project quality objectives and requirements are satisfied.

- Ensures that design meets the applicable codes, standards, requirements, regulations, and DOE directives.

- Provides project management and control services during design and construction.

- Schedules and conducts the design and construction kickoff meetings and progress meetings. Participates in the design review process and management review meetings.

- Reports progress, accumulated cost, and estimate to complete for all services.

- Reviews and approves vendor data submittals. Provides vendor data to the PO based on contractual requirements.

- Maintains systems for design, cost, and schedule baseline change-control documentation for assigned work scope. Provides change documentation to the PO for items that affect baselines established with the PO.

- Provides accurate as-built design for installed systems, structures, and components.

- Prepares and performs the acceptance test procedures (ATP).

- Maintains complete project files including design, construction procedures, and construction schedules. 
- Provides onsite construction management services.

- Administers applicable construction contracts and provides orientation and training for construction subcontractors.

- Provides procurement services as required for construction.

- Performs internal design reviews for constructability, cost effectiveness, and integration with the field work packages.

- Obtains construction site support (HPTs, etc.).

- Completes technical review and turnover of project records to the PO and OC.

- Provides input to the $\mathrm{PO}$ and $\mathrm{OC}$ for operating and maintenance procedures.

\subsection{HANFORD INFORMATION SYSTEM CONTRACTOR (ISC), LOCKHEED- MARTIN SERVICES, INC. (LMSI)}

The information system contractor (ISC) is responsible for maintaining document control and records management systems for the project in accordance with applicable PHMC procedures. The PO will provide copies of project documentation to the ISC, and forward project files to the ISC for archiving. The AE-CM will turn over project documentation to the ISC for incorporation into the PHMC system at project construction completion. 


\subsection{PROJECT MANAGEMENT SYSTEMS AND CONTROLS}

\subsection{WORK BREAKDOWN STRUCTURE}

The WBS depicts the level at which the project will provide reports to the MC. The Project WBS and scope for each activity is contained in the WBS dictionary, Appendix A.

\subsection{BASELINE DEFINITION AND CHANGE CONTROL}

\subsubsection{Baseline Definition}

The technical, cost, and schedule baselines were established through the systematic process of activity planning analyses and cost estimating. The conceptual design (HNF-SDW420-CDR-001, Rev. 1) resulted in the development of a technical work scope baseline, a schedule baseline, and a cost baseline that would support the stack monitoring system upgrade requirements and FFCA milestones. The technical requirements baseline, the technical workscope baseline, the schedule baseline, and the cost baseline provide the baseline definition required to perform definitive design. The performance of definitive design takes the baseline definition to the next level and forms the basis for construction.

The iterative process of increasing technical baseline definition follows the typical process of systems engineering. The PO translates these requirements into design requirements, work scope, schedules, and cost estimates.

\subsubsection{Baseline Change Control}

Changes to the project baselines will be carried out in accordance with approved PHMC procedures. The primary procedures are HNF-PRO-569, Baseline Change Control; HNF-PRO-533, Change Control; HNF-PRO-552, Project Control; HNF-PRO-233, Review and Approval of Documents; and HNF-PRO-440, Engineering Document Change Control Requirements. These procedures define the change control process and documentation requirements and identify the reviewers and approvers. They also identify the threshold levels for changes as they relate to project participants' roles, responsibilities, and authorities. Section 3 of this project execution plan summarizes the project participants' roles in the change control process.

\subsubsection{Technical Change Control and Change Approval}

Changes to the technical baselines will follow the applicable PHMC procedures identified in Section 4.2.2. For technical requirement changes, the key control documents are the FDC, definitive design media, specifications, and the operating procedures. During project execution, the $\mathrm{PO}$ is responsible for ensuring that change control procedures are followed. 
HNF-3011, Rev. 0

The AE-CM produces the definitive design media and obtains approvals commensurate with established thresholds. The AE-CM and the PO control changes to these media during construction and startup. The PO, as a minimum, must approve design changes exceeding cost and schedule threshold limits. The $\mathrm{OC}$ will approve changes to operating procedures.

Technical work scope, developed through the planning process, is summarized in the WBS, WBS dictionary, and multi-year work plans (MYWP). Tasks are assigned to performing organizations for development of detail task definition, cost, and schedule. The PO controls changes to the task definition. Changes to tasks require approval by at least the performing organization and the PO.

\subsubsection{Cost and Schedule Change Control and Change Approval}

Changes to the schedule and cost baselines will follow the applicable PHMC procedures (see Section 4.2.2). The PO controls these two project baselines. Unless directed by RL through the MC, the PO will control project cost to the TPC identified, including the project contingency. Threshold limits identified in the change control procedure define approvals for changes affecting cost. The PO may not exceed the TEC/TPC without approval of the MC and RL. The PO must obtain MC approval of any change that exceeds 25 percent of the total dollar contingency. The AE-CM or design-build contractor may not exceed the contract dollar limit without $\mathrm{PO}$ approval.

The PO also ensures that schedule commitments are maintained. Schedule changes of less than 90 days must be approved by the PO. Changes of greater than 90 days must be approved by the $\mathrm{PO}$ and $\mathrm{MC}$. Changes of greater than 180 days must be approved by the $\mathrm{PO}$, $\mathrm{OC}, \mathrm{MC}$, and RL. Any changes to system construction completion milestones must be approved by the PO, OC, MC, and RL.

\subsubsection{Contractor Change Control Information}

Through the SOW, both the AE-CM and the design-build contractor will be required to maintain a change control log for changes related to technical, cost, and schedule baselines. These change control logs and the change documentation will be available for review by the PO. Monthly progress reports will include a summary of change information.

\subsubsection{Funds Management}

Project funds are authorized by $R L$ for the approved baseline budget shown in Table 1 . This funding is provided to the $\mathrm{MC}$ who, in turn, authorizes funds to the $\mathrm{PO}$ with authorization directives. The $\mathrm{MC}$ issues an authorization directive authorizing funds to the PO. The PO manages these funds through project design, construction, startup, and turnover. Budget provided to the $\mathrm{PO}$ includes expense, capital, and contingency. If yearly budget requirements are not provided or are changed by $\mathrm{RL}$ or $\mathrm{MC}$ direction, the $\mathrm{PO}$ will initiate a change request identifying impacts to work scope, schedules, and costs. 


\subsubsection{Contingency Management}

The PO will receive full budget requirements according to the yearly schedule shown in Table 1. This table identifies the specific contingency that will be managed by the PO. Contingency budget is not intended to be used for changes in work scope. To use contingency for scope changes requires approval by the MC and RL. Use of contingency is at the discretion of the PO.

Contingency is to be used for unplanned events (inclement weather, labor problems, etc.) or estimate deficiencies. The contingency will be loaded in the yearly plans in the last month of the fiscal year (September). The contingency would cover only those activities scheduled to take place during that fiscal year. Drawing from the contingency budget requires a change request approved by the PO. The change request would authorize moving the required contingency budget from the last month to the month needed. At the end of the fiscal year, unused contingency would be distributed to future years through the yearly planning process. The only PO constraint on moving funds from contingency to budget is that a single transfer (change request) does not exceed 25 percent of the total project contingency.

The $\mathrm{PO}$ also must notify the $\mathrm{OC}, \mathrm{MC}$, and $\mathrm{RL}$ when 50 percent, 75 percent, and 90 percent of the project's total contingency has been used. This notification requirement is based on PHMC procedure HNF-PRO-533, Change Control.

\subsection{RISK MANAGEMENT, PERFORMANCE MONITORING, REPORTING, AND FORECASTING}

\subsubsection{Risk Management}

The project will be executed to accomplish a well-defined mission to support the FFCA milestones and Hanford Site sampling. Extensive interfacing and functional analyses have been performed to establish the project's technical requirements and scope, and determine the risks associated with the final safety analysis report (FSAR) risk, procurement, construction in a radiation zone, and testing.

\subsubsection{Performance Monitoring, Reporting, and Forecasting}

The PO will monitor project performance and evaluate the performance monthly. The PO will report to the MC and RL monthly. The report will comply with HNF-PRO-567, Monthly and Quarterly Progress Reports. The information also will be discussed at monthly review meetings. The PO will provide copies of the report to all project participants and keep them informed on all issues and progress toward meeting milestones. The PO report will incorporate information from the major performing organizations.

Table 1 and Figure 1 identify the activity level that the report will address. The multiyear program plan provides the monthly budgeted cost of work planned based on the Table 1 cost objectives. Using the Site's earned value method analyses, performance is analyzed 
monthly. Contract flow-down requirements dictate that the AE-CM evaluate performance and report their findings to the PO. Each monthly report will include an estimate to complete.

\subsection{PROJECT MEETINGS AND COMMUNICATIONS}

\subsubsection{Project Meetings}

Three types of formal meetings will be conducted during this project: design meetings, construction meetings, and management review meetings. The PO is responsible for establishing the design meeting schedule in concert with the design agent. The design meetings include design progress, design review kickoff, and design review comment resolution. The PO will notify other participants of these monthly meetings and document the proceedings. Design review meetings are planned to be held when the design is 30-, 60-, and 90-percent complete.

Construction project meetings will be held monthly and scheduled jointly by the PO and the construction manager. These meetings will be conducted and documented by the construction manager. Attendees will include the PO, the construction manager, and organizations with operational responsibilities for systems under construction.

Management review meetings will be held monthly and will be attended by the PO, MC, $\mathrm{AE}-\mathrm{CM}$ and $\mathrm{WMC}$, as needed. The meetings will be scheduled, conducted, and documented by the PO. The PO will prepare and issue project reports and narratives for review at the meetings, for presentation of project status, and for resolution of action items.

In addition to the formal meetings listed above, interface management meetings will be conducted by the PO during design, construction, and testing activities.

\subsubsection{Communications}

Project decisions, direction, status, report transmittals, and technical information transmittals must be documented with formal letters. The PO will determine distribution of the documentation and will maintain the project file, which must include a copy of all formal communications. The project file need not include internal communications of other participating organizations; however, each company must maintain a file of all internal communications relevant to project execution.

Teleconferences will be documented if they provide information critical to project execution. The PO will establish distribution for teleconference notes.

\subsection{CONFIGURATION MANAGEMENT}

Before turnover of as-built drawings, specifications and procedures for operations, configuration management $(\mathrm{CM})$ responsibilities are split between the Site's performing organizations ( $\mathrm{PO}, \mathrm{OC}, \mathrm{MC}$, and $\mathrm{WMC}$ ) and the design and construction contractor (AE-CM). 
$\mathrm{CM}$ for the project focuses on the technical baseline products developed during the preconceptual stage and the conceptual design, design-build, startup, and turnover phases. The final facility configuration turned over to the operations contractor is a product developed progressively from functional design criteria (FDC), conceptual design criteria (CDR), definitive design criteria (DDC) (detail design and specifications), construction (vendor technical information), final testing (procedures and reports), and turnover of completed operational facilities (as-built configurations). Control of these products leading to the final configuration is the purpose of the project's configuration management activities.

\subsubsection{Design Media Control}

Design documents include detail design drawings, specifications, and vendor technical information. These documents are controlled by the design agents using their internal procedures. The SOW will require the design agent to implement a design control system. The $\mathrm{PO}$ is responsible to ensure that an adequate design control system exists. The initial detail design is approved by the PO, IC, or WMC using HNF-PRO-445. Approval indicates the design meets the design requirements. The PO turns over configuration management responsibility to the OC by releasing the as-built design media into the PHMC-TWRS document control system using PHMC and TWRS procedures. The two key procedures are HNF-PRO-244 and HNF-PRO-317. Before turnover and early in the definitive design, the $\mathrm{OC}$ will define which design media will be considered essential to configuration management. Throughout the design, construction, startup, as-built, and turnover processes, these essential design media will be maintained under configuration control.

\subsection{AUDITS, SURVEILLANCES, AND ASSESSMENTS}

The project will be subjected to independent oversight including audits, surveillances, and assessments. Internally the project will perform surveillances of the contractors working on the project. These surveillances would occur during the design, construction, and startup phases. At its discretion but at least annually, the $\mathrm{PO}$ also will perform independent management assessments of the project.

The MC facility evaluation board also may audit this project. $\mathrm{RL}$ also may conduct audits or surveillance of the project. RL oversight focuses on compliance with DOE orders and directives.

The applicable PHMC procedures are HNF-PRO-1837, Cooperating with Outside Audits, Inspections, and Investigations, and HNF-PRO-333, Responding to Internal Audits. 


\subsection{PLANNING}

\subsection{QUALITY ASSURANCE PLAN}

A project-specific quality assurance plan, HNF-3285, Quality Assurance Program Plan for Project W-420 (Stack Monitoring System Upgrades) (Anderson 1998), has been prepared for this project. Work performed by the $\mathrm{MC}, \mathrm{OC}$, and $\mathrm{PO}$ will be covered by this project-specific quality assurance program plan (QAPP). The subcontractors will either use this PHMCapproved QAPP, or develop a project-specific QAPP for approval by the PO; PHMC quality assurance requirements will flow down to the subcontractors.

The W-420 project-specific QAPP will be implemented using a graded approach. Ensuring quality on this project focuses on meeting technical, cost, and schedule objectives, and continuity of operation. Quality work performance and products are essential to this project.

This project execution plan identifies the PHMC procedures that will be required to execute the project with the appropriate level of control. These procedures apply only to work being performed by the $\mathrm{MC}$ and major subcontractors. The other subcontractors may use their own procedures. Several procedural requirements will be included in the subcontractors' SOW or contract. These include, but are not limited to, drawing formats, vendor information documentation, and control of suspect or counterfeit items.

Sufficient oversight will exist during design, procurement, construction, and startup activities. PHMC procedures for design verification will be used. Subcontractors will use quality control procedures to ensure proper inspection of fabricated parts and construction processes. Inspection, witnessing, and record reviews will occur during all phases of the project through startup.

\subsection{ENGINEERING}

The engineering process used on this project will comply with PHMC procedures. The engineering activities focus on the PO's and OC's responsibility for allocating and tracking project technical support tasks and document reviews. Design is performed by external design agents following their own engineering procedures and is approved by the OC and PO. Specific PHMC procedures relative to drawing format will be imposed on the design agent.

\subsubsection{Requirements Definition}

The PO has overall responsibility for coordinating the efforts needed to keep requirements definition up to date. HNF-PRO-561, Functional Design Criteria, provides guidance for requirements definition. 
HNF-3011, Rev. 0

\subsubsection{Waste Minimization and Pollution Control}

This project will comply with the requirements of HNF-PRO-462, Pollution Prevention, which includes requirements related to pollution control and waste minimization.

\subsubsection{Systems Engineering}

Project requirements development has followed good systems engineering practices. Requirement documents have been linked to the RL-specific requirements with flow-down through the $\mathrm{MC}, \mathrm{OC}$, and WMC. Requirements and analyses have undergone peer and customer reviews. Interfaces have or will be clearly defined. All documents are subject to change control using PHMC procedures or design agent procedures.

\subsubsection{Document Reviews}

Project documents have been or will be subjected to both peer and customer reviews. HNF-PRO-445, Design Verification Requirements, HNF-PRO-233, Review and Approval of Documents, and HNF-PRO-317, Engineering Release and Approval Requirements, will be used to control the document reviews, approval, and release into the PHMC document control system. Design verification will consist of reviews that will be documented.

Design authorities for the $\mathrm{OC}$ will review and approve documentation that defines the facilities and system they will be operating. Changes to approved design media during construction will be subject to review if the changes affect the design requirements.

\subsection{ENVIRONMENTAL COMPLIANCE}

The project is evaluated for compliance to the National Environmental Policy Act of 1969 (NEPA) documentation. The project will review existing state and local permits for impacts caused by the new facilities or systems. HNF-PRO-452, NEPA, SEPA, Cultural and Natural, Resources, and HNF-PRO-569, Baseline Change Control, are used in evaluating project compliance with NEPA.

In accordance with 40 CFR 61, Subpart $\mathrm{H}$ and the Washington State Administrative Code (WAC) 246-247, "Radiation Protection - Air Emissions," a notice of construction (NOC) will be prepared for the project to document potential airborne emissions from the project's construction activities. The NOC will be submitted for approval to the U.S. Environmental Protection Agency, Region 10, and the Washington State Department of Health.

\subsection{SAFETY}

Preliminary safety evaluations of the project are being performed during the conceptual design phase. Safety evaluations follow HNF-PRO-062, Identifying and Resolving Unreviewed Safety Questions. The SAC is performing the USQ screenings. During the definitive design 
HNF-3011, Rev. 0

phase, the USQ screening will be repeated to ensure that no changes have occurred in the hazards associated with the project. No changes are anticipated to the TWRS authorization basis as a result of these screenings.

See HNF-3285, Quality Assurance Program Plan for Project W-420 (Anderson 1998), for a discussion of the safety aspects of the procurement process.

Personnel safety during construction will follow the requirements of HNF-PRO-074, Safety Responsibilities. Accident reporting and investigations will be performed in accordance with HNF-PRO-077, Reporting and Investigating, Accidents.

\subsection{TESTING AND EVALUATION}

Project testing and evaluation consists of design verification, inspections, and testing. Design verification will be conducted by the $\mathrm{PO}$ during definitive design. This verification will determine whether the detail design media comply with the design requirements. After the design has been approved, the design agent and PO will control the design change process to ensure that compliance with design requirements is not compromised.

The AE-CM will establish quality control (QC) programs that will include in-process inspection of the systems, structures, and components being built. This QC program will be reviewed, approved, and monitored by the $\mathrm{AE}-\mathrm{CM}$. The intent of the $\mathrm{QC}$ program is to verify that what is being fabricated, constructed, installed, and tested complies with the detail design, specifications, and ATP.

The $\mathrm{MC}$ will use a detailed acceptance inspection (AI) plan to conduct $\mathrm{AI}$ for the government for all project systems.

Testing and evaluation will include construction inspections, acceptance testing, and independent acceptance inspection to ensure compliance to the project requirements. Project requirements for testing and evaluation will be passed on to the $\mathrm{AE}-\mathrm{CM}$ via a SOW or specification.

Acceptance testing will be performed in the field to demonstrate that all components function to meet the intent of the design. ATPs will be developed by the AE-CM and approved by the design authority, PO, and MC. The AE-CM will perform ATPs and prepare ATP reports. The AE-CM, design authority, and MC will approve the ATP reports.

Independent $\mathrm{AI}$ will be performed by the $\mathrm{MC}$ quality assurance organization on behalf of $\mathrm{RI}$. The MC quality assurance organization will prepare an AI plan concurrent with the detailed design review. The AI plan will be reviewed by the projects and design authority and approved by RL in accordance with HNF-PRO-1997, Construction Program Overview. The acceptance inspector will witness key attributes during construction, testing, and construction completion; validate as-built drawings; and conduct electrical code compliance inspections. The detailed construction inspection will be performed in accordance with the construction contractor's quality assurance program. 
HNF-3011, Rev. 0

\subsection{PROJECT TURNOVER}

The project turnover task will be executed by the PO with support from the AE-CM, the $\mathrm{OC}$, the WMC, and the MC. HNF-PRO-572, Project Acceptance and Closeout will be used to accept the new and modified systems for beneficial use and close out the project. Table-2 identifies the roles and responsibilities of the organizations involved in as-built drawings, construction completion and cost-close $(4 \mathrm{Cs})$ documentation, official acceptance of construction (OAC) and training.

Before project turnover, the PO and $\mathrm{OC}$ will develop operating procedures and train personnel in the operation and maintenance of new systems. The AE-CM will provide support and input during these transition activities.

The PO will ensure that all $\mathrm{AI}$ issues are satisfactorily resolved and dispositions documented. 


\subsection{REFERENCES}

40 CFR 61 "National Emission Standards for Hazardous Air Pollutants," Code of Federal Regulations, as amended.

ANSI, 1974, American National Standard Specification and Performance of On-Site Instrumentation for Continuously Monitoring Radioactivity in Effluents, Standard N13.1, American National Standards Institute, New York, New York.

Crummel, G. M., 1998, Determination of the NESHAP Status of Tank Farms' Stacks Based on Calculations Using 40 CFR, Part 61, Appendix D Factors, HNF-SD-WM-EMP-031, Rev. 3/3A, Lockheed Martin Hanford Company, for Fluor Daniel Hanford, Inc., Richland, Washington.

DOE O 430.1, Life Cycle Asset Management, U.S. Department of Energy, Washington, D.C.

DOE Order 4700.1, Project Management System, U.S. Department of Energy, Washington, D.C.

EPA, 1994, Federal Facilities Consent Agreement, U.S. Environmental Protection Agency, Washington, D.C.

HNF-PRO-062, Identifying and Resolving Unreviewed Safety Questions, Fluor Daniel Hanford, Inc., Richland Washington.

HNF-PRO-233, Review and Approval of Documents, Fluor Daniel Hanford, Inc., Richland, Washington.

HNF-PRO-317. Engineering Release and Approval Requirements, Fluor Daniel Hanford, Inc., Richland, Washington.

HNF-PRO-333, Responding to Internal Audits, Fluor Daniel Hanford, Inc., Richland, Washington.

HNF-PRO-440, Engineering Document Change Control Requirements, Fluor Daniel Hanford, Inc., Richland, Washington.

HNF-PRO-445, Design Verification Requirements, Fluor Daniel Hanford, Inc., Richland, Washington.

HNF-PRO-452, NEPA, SEPA, Cultural and Natural, Resources, Fluor Daniel Hanford, Inc., Richland, Washington.

HNF-PRO-462, Pollution Prevention, Fluor Daniel Hanford, Inc., Richland, Washington.

HNF-PRO-533, Change Control, Fluor Daniel Hanford, Inc., Richland, Washington.

HNF-PRO-551, Construction Program, Fluor Daniel Hanford, Inc., Richland, Washington. 
HNF-PRO-552, Project Control, Fluor Daniel Hanford, Inc., Richland, Washington.

HNF-PRO-561, Functional Design Criteria, Fluor Daniel Hanford, Inc., Richland, Washington.

HNF-PRO-567, Monthly and Quarterly Progress Reports, Fluor Daniel Hanford, Inc., Richland, Washington.

HNF-PRO-569, Baseline Change Control; Fluor Daniel Hanford, Inc., Richland, Washington.

HNF-PRO-572, Project Acceptance and Closeout, Fluor Daniel Hanford, Inc., Richiand, Washington.

HNF-PRO-1837, Cooperating with Outside Audits, Inspections, and Investigations, Fluor Daniel Hanford, Inc., Richland, Washington.

HNF-PRO-1997, Construction Program Overview, Fluor Daniel Hanford, Inc., Richland, Washington.

Tuck, J. A., 1998, Conceptual Design Report for Project W-420, Stack Monitoring Upgrade, HNF-SD-W420-CDR-001, Fluor Daniel Northwest Services, Inc., for Fluor Daniel Hanford, Inc., Richland, Washington.

National Environmental Policy Act of 1969, 42 USC 4321, et seq.

Anderson, T. Z., 1998, Quality Assurance Program Plan for Project W-420, HNF-3285, Fluor Daniel Northwest Services, Inc., for Fluor Daniel Hanford, Inc., Richland, Washington

Tuck, J. A., 1998, Functional Design Criteria for Project W-420, Stack Monitoring Upgrade, HNF-SD-W420-FDC-001, Fluor Daniel Northwest Services, Inc., for Fluor Daniel Hanford, Inc., Richland, Washington.

WAC 246-247, 1990, "Radiation Protection-Air Emissions," Washington Administrative Code, as amended. 
HNF-3011, Rev. 0

APPENDIX A

WORK BREAKDOWN STRUCTURE 
HNF-3011, Rev. 0

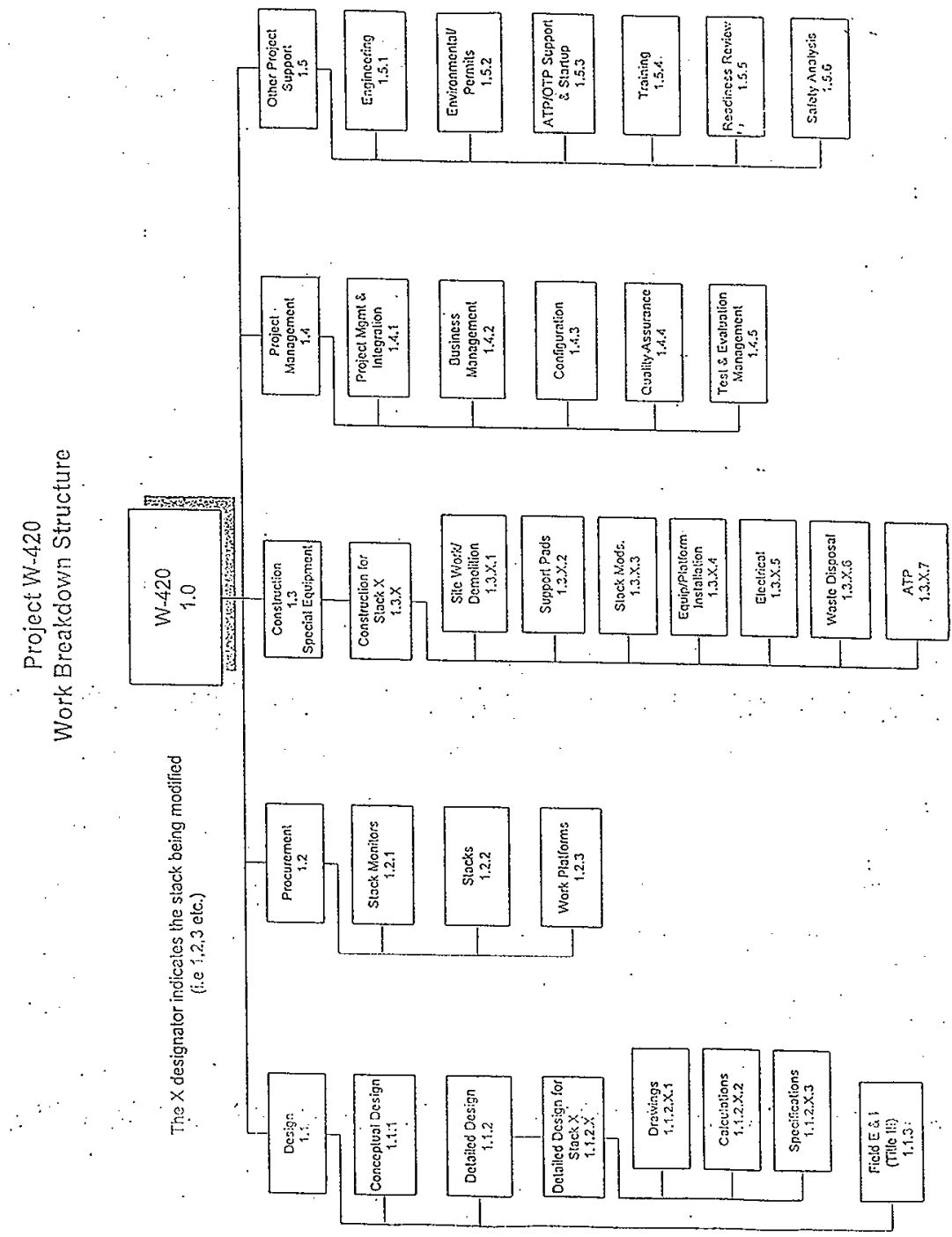




\begin{tabular}{|c|c|c|c|}
\hline $\begin{array}{l}\text { 1. Dictionary Title: } \\
\text { Environmental } \\
\text { Compliance } \\
\text { Program }\end{array}$ & $\begin{array}{l}\text { 2. Date: } \\
08 / 04 / 98\end{array}$ & $\begin{array}{l}\text { 3. PBS Number: } \\
\text { RL-OT01 }\end{array}$ & $\begin{array}{l}\text { 4. Dict Rev: } \\
0\end{array}$ \\
\hline $\begin{array}{l}\text { 5. WBS No.: } \\
1.8 .2 .3 .11\end{array}$ & $\begin{array}{l}\text { 6. B\&R No.: } \\
\text { EW0290700 }\end{array}$ & \multicolumn{2}{|c|}{ 7. Baseline CR No:: } \\
\hline \multirow{2}{*}{\multicolumn{4}{|c|}{$\begin{array}{l}\text { 8. Organization Name: Environmental Compliance Program } \\
\text { 9. Scope of Work: }\end{array}$}} \\
\hline & & & \\
\hline \multicolumn{4}{|c|}{ W-420 Stack Monitoring System Upgrades (1.8.2.3.11), FDS WBS 1R1H11: } \\
\hline \multicolumn{4}{|c|}{$\begin{array}{l}\text { This project executes the design, procurement, construction, startup and turnover } \\
\text { activities for stack monitoring system upgrades on selected Tank Waste Remediation } \\
\text { System (TWRS) ventilation systems. FY } 1999 \text { objectives include definitive design, } \\
\text { procurement of material, permitting, and the initiation of construction. The technical } \\
\text { objectives for representative sampling of ventilation exhaust streams are based on } \\
\text { historical data from Hanford and other DOE sites. The project will modify existing } \\
\text { facilities and provide compliant monitoring systems for six Tank Waste Remediation } \\
\text { System (TWRS) "major" ventilation system stacks. Major stacks must meet the } \\
\text { monitoring requirements of } 40 \text { CFR } 61 \text { Subpart H. }\end{array}$} \\
\hline \multicolumn{4}{|c|}{$\begin{array}{l}\text { The six stacks requiring upgrades for compliant sampling are: 296-A-25 (244-A DCRT), } \\
\text { 296-B-28 (244-BX DCRT), 296-C-5 (244-CR Vault), 296-P-16 (241-C Tank Farm), 296- } \\
\text { S-22 (244-S DCRT), and 296-T-18 (244-TX DCRT). }\end{array}$} \\
\hline \multicolumn{4}{|c|}{$\begin{array}{l}\text { For the purposes of this project, "start of construction" for all six stacks shall be defined } \\
\text { as: "place concrete pads before June } 30^{\text {th }} \text { to meet the six legally enforceable Federal } \\
\text { Facility Compliance Agreement (FFCA) milestones". }\end{array}$} \\
\hline
\end{tabular}




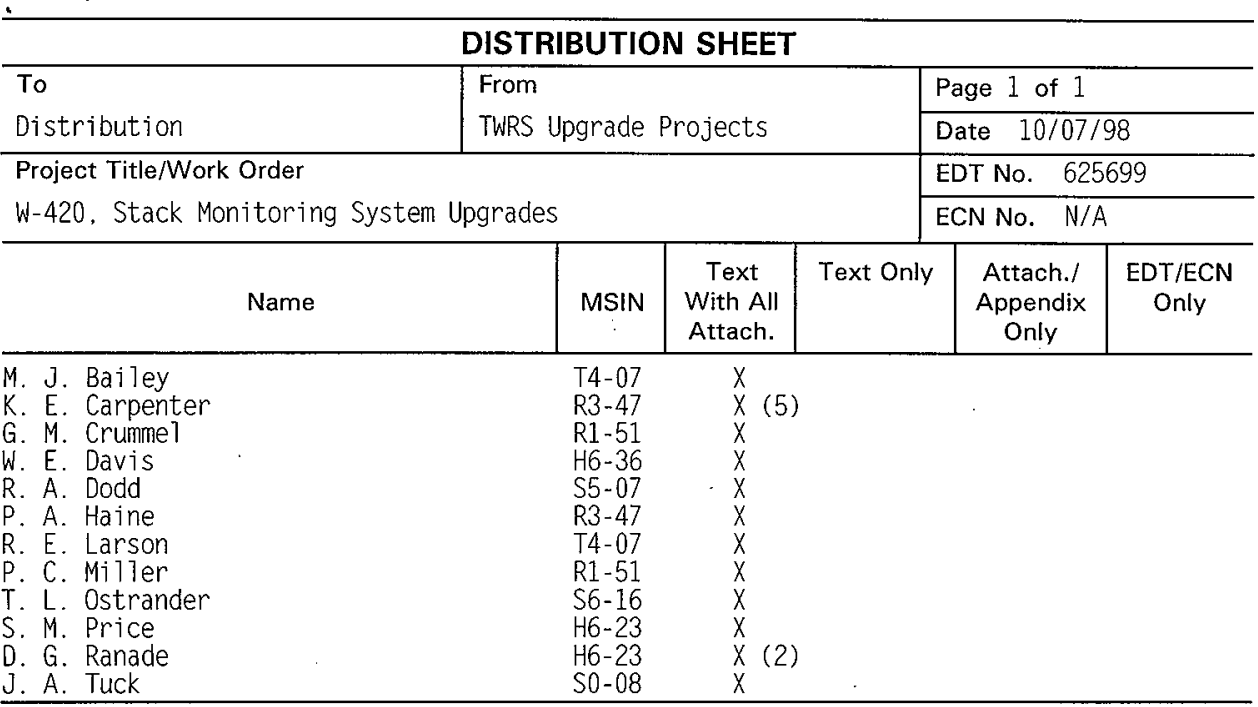

